\title{
ПАСІОНИ: ЖАНРОВІ ІНТЕНЦІЇ КОМПОЗИТОРІВ ТРЕТЬОГО ТИСЯЧОЛІТТЯ
}

\author{
Савонюк Г. О.
}

\section{ВСТУП}

Сучасне безмежжя світового мистецтва 3 кожним роком упевнено розширює свій простір, виходячи за рамки жанрових канонів, наявних жанрово-стильових моделей, усталених композиційних форм музичних творів. Бажаючи максимально розкрити потенціал людини творчої, художники-митці відкривають нові горизонти для своєї діяльності не тільки за рахунок креативно-творчого підходу до нових мистецьких проєктів, а й завдяки переформатуванню жанрово-композиційних зразків минулого.

Останнім часом музичні інтенції композиторів усе більше спрямовані на розкриття особистого творчого потенціалу в площині творів із сакральним наповненням. Така художня зосередженість композиторів, по-перше, пояснюється їх бажанням звернутися до традицій Середньовіччя (як відомо, головною функцією музики тих часів було ії призначення прославляти Бога). По-друге, зацікавленість духовними творами на території пострадянського простору саме сьогодні є резонансною хвилеювідповіддю творчого підйому на довгий сімдесятирічний етап так званого «духовного замовчування». По-третє, нині, щонайменше, всі розвинуті країни світу сконцентровані на збереженні багатогранного світового культурного досвіду всесвіту, що має на увазі важливість відтворення індивідуальності кожної окремої культури.

Отже, українське мистецтво, переживаючи новий етап, звертаючись до свого національного минулого, вивчає його 3 нових ракурсів, переосмислює, наповнює новим смислом. Жага нових відкриттів, знахідок особливо надихають митців, надаючи їм безліч можливостей осучаснення творів минувшини. Композитори сьогодення задля модернізації мистецького простору, заради утворення оновленого звукового матеріалу експериментують не тільки із розмаїттям тембральних забарвлень інструментального звучання, але й продовжують мовленнєвознакові та жанрово-стильові пошуки. Композитори натхненно створюють новітні зразки транскрипцій прадавніх композицій, спираючись на твори 3 християнською тематикою.

Так, незліченна кількість музичних полотен відтворюють картини життя головного персонажа Нового Заповіту - Ісуса Христа. Великий пласт мистецького простору відведено одному з найдавніших музичних 
жанрів, в якому йдеться про останні дні земного життя, часи нелюдського страждання, незаслужену страту та пророковане воскресіння Месії. Чотири євангелісти: Матвій, Марк, Лука та Іван доносять «радісну звістку» (Євангеліє) про воскресіння Iсуса, даруючи віруючим надію на нескінчене життя. Від Івана [3:36] «Хто вірує в Сина, той має вічне життя...»» ${ }^{1}$.

Пасіони (страсті) - музичні твори, що написані за євангельською тематикою, вже понад п’ятсот років не втрачають своєї актуальності. Їх насущна роль у наш час підтверджується появою великої кількості композицій, що мають в своїй основі страсний сюжет.

Страсті сьогодення активно досліджуються науковцями зарубіжних країн. Так, результатом пошуків російського науковця Свгенії Рау стала дисертація «Жанр пассиона в музыкальном искусстве: общий исторический путь и судьба в XX-XXI вв.» $(2018)^{2}$. Жанр страстей репрезентує i книга "Contemporary Music and Spirituality" (2016) ${ }^{3}$. У першій главі видання йдеться про історичні віхи жанру з 1965 року. У книзі приділено увагу пасіонам естонського композитора А. Пярта ("Passio Domini nostri Jesu Christi secundum Joannem", 1982), страстям шотландця Джеймса Макміллона "St John Passion" (2008) та масштабному музичному проєкту "Passion-2000". До останнього були долучені композитори різних країн: росіянка Софія Губайдуліна, німець Вольфганг Рім, американець Освальдо Голіхов (батько якого був українцем) та китайсько-американський митець Тан Дун. Видання, в якому представлено широку панораму мистецьких робіт, присвячених страсним подіям, є книга О. Ябруха (Oliver Larry Yarbrough) "Engaging the Passion: Perspectives on the Death of Jesus Paperback" (2015) 4 .

В українському музикознавстві жанр пасіонів $\epsilon$ маловивченим. «Страсті Господа Бога Нашого Ісуса Христа» львівського композитора О. Козаренка досліджено в статтях та дисертації А. Ткаченко «Українська сакральна монодія в сучасній композиторській творчості» $(2016)^{5}$. У роботах О. Коменди ${ }^{6}$ жанр представлено 3 позицій вивчення

1 Біблія / в перекл. Огієнка I. URL : https://bibleonline.ru/bible/ubio/jhn-3/ (дата звернення: 17.07.2020). Такий переклад Біблії використовується для всієї роботи.

2 Рау Е. «Жанр пассиона в музыкальном искусстве: общий исторический путь и судьба в ХХXXI вв» : дис. ... канд. искусств. Рос. гос. пед. ун. им. Герц. 17.00.02. Санкт-Петербург. 2018. 329 с. URL: https://www.conservatory.ru/sites/default/files/uploads/science/.pdf. (дата звернення: 17.07.2020).

3 Contemporary Music and Spirituality. Robert Sholl, Sander Van Maas edition. 2016. URL: https://www.routledge.com/Contemporary-Music-and-Spirituality-1 st-Edition/Sholl-Van-Maas/p/book. (дата звернення: 17.07.20).

Yarbrough O. L. Engaging the Passion: Perspectives on the Death of Jesus. 2015. URL: https://www.jstor.org/stable/j.ctt13wwwjn. (дата звернення: 17.07.20).

5 Ткаченко А. Українська сакральна монодія в сучасній композиторській творчості : дис. ... канд. мист. Львів. нац. муз. акад. ім. М.В. Лисенка. Львів. 2016. 183 с. URL: http://conservatory.lviv.ua/wpcontent/uploads/2016/09/diss-tkachenko.pdf (дата звернення: 17.07.2020).

6 Коменда О. Жанрово-інтонаційні джерела тематизму Олександра Козаренка: інтонаційні відкриття композитора. С. 141-157. URL: https://core.ac.uk/download/pdf/153584885.pdf (дата звернення: 17.07.20). 
творчого доробку композиторів України ${ }^{7}$. Сучасні зразки пасіонів потребують всебічного наукового дослідження задля виявлення нових напрямів у разі написання страстей у творчості композиторів останнього тисячоліття.

\section{1. Пасіони - п'яте, нескінчене Свангеліс}

У «Словнику біблійних образів» «під страстями (англійське слово passion походить від латинського раtio - «страждати» або «зазнавати») Христовими маються на увазі події, щяо охоплюють період, який отримав назву Страсного тижня - від в'їзу Iсуса в Срусалим в неділю до другого дня поховання в суботу. У другу неділю відбулося воскресіння. Головний герой иих подій - Сам Христос: ие від початку до кіния історія Його страждань і смерті» ${ }^{8}$.

Що впродовж багатьох століть спонукає композиторів до створення нових зразків пасіонів?.. По-перше, це унікальність такого жанру, яка $\epsilon$ очевидною. Пасіони - єдиний з багатьох тисяч музичних жанрів, присвячений долі Христа як окремій особистості. В терміні «страсті» акумульовано:

- жанрову приналежність;

- наявність повного сюжету з ії незмінним головним героєм - Ісусом.

Пасіони - жанр ємно-цілісний, програмний. У страстях сконцентровано головну християнську доктрину: дати людям надію на довічне життя, до якого підсвідомо прагне кожна людина.

«У літературному плані Євангелія являють сукупність творів енииклопедичного характеру, в яких об'єднані доволі різні жанри. До них належать біографічні описи, історичні оповідання, розповідь про героя, хроніки поточних подій, іносказання, драматичні сиени, діалоги, проповіді чи притчі, прислів'я чи приказки, сатира, поезія, трагедія $i$ комедія» ${ }^{9}$. Апогеєм євангельських розповідей, всієї історії про Ісуса та жанрового сенсу пасіонів стає золотий вірш: Від Івана [3:36]: «Хто вірує в Сина, той має вічне життя...».

Унікальність літературної основи пасіонів вбачається в тому, що:

1) Свангеліє пов'язано 3 таємницею минулого, теперішнього та майбутнього, тобто історія Христа нескінчена і іï не буде завершено, доки існує Земля;

2) Свангеліє розповідає про ірреальність буття: про те, чому немає аналогів серед подій повсякденності, але має місце присутність дива

\footnotetext{
${ }^{7}$ Коменда О. Універсальна творча особистість в українській музичній культурі : дис. ... докт. мист. : 17.00.03. Нац. муз. акад. Укр. ім. Чайк. Київ: 2020. 519 с. URL: http://knmau.com.ua/wpcontent/uploads/komenda-dysertatsiya.pdf (дата звернення: 17.07.2020).

8 Райкер Л., Уилхойт Д., Лонгман Т. Словарь библейских образов. URL: https://azbyka.ru/ otechnik/Spravochniki/slovar-biblejskih-obrazov/723 (дата звернення: 17.07.20).

${ }_{9}$ Райкер Л., Уилхойт Д., Лонгман Т. Словарь библейских образов / перевод Скороходова Б.А., Рыбакова O.A. URL: https://azbyka.ru/otechnik/Spravochniki/slovar-biblejskih-obrazov/723 (дата звернення: 17.07.2020).
} 
(так, Христос зцілював хворих, воскрешав померлих, у Кані Галілейській - перетворював воду на вино: від Івана [2:11] «Такий початок чудам зробив Ісус у Кані Галілейській»);

3) Свангеліє має прадавні витоки та водночас вміщує в собі сучасне бачення реалій світу (у тому ж числі завдяки новим мистецьким інтерпретаціям).

Магнетизм дії від прочитання Біблії (і Свангелія) вже близько двох тисячоліть вбачається в тому, що вона $є$ книгою і архаїчною, і сучасною (наприклад, завдяки перекладам). Більш того, тривимірність існування Писання знаходимо в тому, що Біблія - літературне джерело, що розповідає про минуле, пов'язане з нашим часом і прогнозує майбутнє (в її останній частині Одкровення). Амбівалентність сутності Біблії полягає в тому, що всіх, зрозумівших Священне Писання, вона навчить мудрості, інших - введе в стан непорозуміння, непотрібності їі прочитання взагалі.

«Слово Біблія походить від латинського слова biblia, щео означає «невеликі книги» $i$ вказуе на факт, щяо ия книга є антологією творів, написаних різними авторами протягом багатьох століть, що охоплюють звичайне коло жанрів і стилів» ${ }^{10}$. Митці знов і знов черпають своє натхнення в Священному Писанні, що є найпопулярнішою книгою Всесвіту. «Біблія - єдина книга, проти якої повставали полчища супротивників протягом тисячоліть. Незліченну кількість книг, написаних проти Біблії, розбилося об неї, як розбивається молот про ковадло, а вона - жива. Чимало книг, щь порочать Біблію, з часом були викинуті на звалище історії, вони -мертві, віджили свій вік, розбившись об скелю Писання». ${ }^{11}$ Книга Біблія, розповідаючи про історію Землі від самого іiі утворення, $\epsilon$ найдавнішим культурним пам'ятником людства.

Досконалість Біблії, іiі невичерпна глибинність, щонайменше, полягає в:

- цілісно-духовній спрямованості;

- наявності тексту морально-виховного смислу (так, повчальними $\epsilon$ псалми Давида (всього 150), приповісті царя Соломона (всього 31));

- лірично-поетичній досконалості (Пісні Піснів Соломона (всього 8) $є$ прикладом неперевершеної любовної лірики);

- історичній значущості (Писання $є$ найстарішою книгою, що дійшла до наших часів, будучи зразком стародавньої культури).

Прадавні зразки Біблії як найцінніші артефакти збережено до наших днів. Так, у Римі знаходиться Ватиканський (IV ст. н. е.), в Оксфорді Сінайський (IV ст. н.е.), в Британському музеї - Олександрійський (V ст. н. е.) манускрипти.

\footnotetext{
${ }^{10}$ Райкер Л., Уилхойт Д., Лонгман Т. Словарь библейских образов / перевод Скороходова Б.А., Рыбакова O.A. URL: https://azbyka.ru/otechnik/Spravochniki/slovar-biblejskih-obrazov/723. (дата звернення: 17.07.2020).

11 Юнак Д.О. «Миф или действительность». URL: http://www.nauka.bible.com.ua/mif/index.htm (дата звернення: 17.07.20).
} 
Особливо вагомим складником Священного Письма, який не можна виміряти, $є$ іiі насиченість енергетикою тих людей, які стояли за іiі написанням, збереженням та на певних етапах за іï відтворенням. На жаль, не всі їхні імена збереглися до сьогодні. Так, Старий Заповіт написано у 1521-397 роки до н.е. різними авторами. Новий Заповіт складався у 57-96 роки н. е. учнями та апостолами Ісуса. «Канонічні книги Старого Заповіту було зібрано докупи богонатхненним книгарем Єздрою, який жив приблизно за 450 років до Р. Хр.» ${ }^{12}$ «У 277 роиі до Р. Хр. сімдесятьма двома «тлумачами» (перекладачами) був завершений переклад Старого Завіту з давньоєврейської на грецьку мову, який названий Септуагінтою, щзо означає - «сімдесят» ${ }^{13}$. Сучасний розподіл Біблії на глави та вірші маємо завдяки Кентенберійському епіскопу Стефану Лангтону, який розпочав цю працю, та його послідовникам Сантесу Паніно та Роберу Етьєну (Стефанусу).

Біблію писали впродовж 1600 років ${ }^{14}$. До створення Старого Заповіту долучилися двадцять три особи: Мойсей, Ісус Навін, Самуїл, Сремія, Єздра, Неемія, Давид, Соломон, Ісая, Єзекіїль, Даніїл, Осія, Йоїл, Амос, Овді, Йона, Михей, Наум, Авакум, Софонія, Огій, Захарія, Малахія. Вісім мужей Божих писали канон Свангелія: Матвій, Марк, Лука, Іван, Яков, Петро, Юда, Павло.

Як у написанні Священної Книги були задіяні лише чоловіки, так і у iï перекладі маємо історичні відомості лише про осіб чоловічої статі. Назвемо імена людей, які були причетні до перекладу Біблії на різні мови, оскільки їхня праця сприяла появі музичних пасіонів у різних країнах. Так, у часи Реформації Мартін Лютер (1483-1546) - священник 3 Німеччини - впродовж двадцяти років життя (1522-1542 рр.) перекладав Біблію на німецьку. Перекладені ним Свангелія стали стимулом для написання перших німецьких пасіонів його товаришем Йоганном Вальтером (Johannes-Passion, 1530).

Післяреформаційний період становить найплідніший період для розквіту пасіонів. Цілком зрозуміло, що в цей час народжуються музичні страсті 3 національною окраскою. Тільки в Німеччині з'являються пасіони Генріха Шютца (Johannes-Passion, 1666), Георга Генделя (Brockes Passion, 1719). Вершинні пасіони вийдуть 3-під пера Йогана Баха (Matthäus-Passion), композитор напише їх за біблійними текстами, перекладеними саме М. Лютером (як відомо, арії, хори, хорали переосмислить лібретист К.Ф. Хенріці (Пікандер). Перша бахівська версія «Страстей за Матвієм» з'явиться у 1727-29 роки, друга вийде у 1736 p.

\footnotetext{
12 Tам само.

13 Там само.

${ }^{14}$ Там само.
} 
Творчість сучасника Й. Баха, його друга Георга Телемана (1681-1767), на жаль, з роками стане незаслужено забутою. Ось що напише про це Ромен Ролан: «У той день, коли було визнано велич I.C. Баха, все, що було великого в його час, звернулося в менш ніж ніщо. Насилу прощається Генделю зухвалість володіти таким же генієм, який був у І.С. Баха, і мати набагато більший успіх. Решта звернені в прах; $і$ більше всіх - Телеман, якого потомство змусило розплатитися за нечувану перемогу, здобуту ним за життя над I.C. Бахом» ${ }^{15}$. Залишивши багату творчу спадщину, Г. Телеман вніс великий вклад у розвиток жанру страстей, серед його творів нараховується сорок шість зразків пасіонів ${ }^{16}$.

Очевидно, що переклад Біблії М. Лютером (як і вся реформаторська діяльність загалом) мав великий резонанс в усіх сферах життя. Але знадобилось близько сорока років від моменту повного перекладу Біблії в Німеччині до іï першого повного видання церковнослов'янською в Україні (Біблії Острозької, 1581). Остання з'явиться в Острозі завдяки зусиллям мецената князя Костянтина-Василя Острозького, вченим Острозької школи та друкарю Івану Федорову.

Проведемо паралелі між появою перших перекладів Священного Письма та народжених на їх основі окремих пасіонів різних країн світу. Результати дослідження зведено в таблицю 1.

Таблиця 1

\begin{tabular}{|c|c|c|c|c|}
\hline № & $\begin{array}{c}\text { Автор } \\
\text { пасіонів }\end{array}$ & $\begin{array}{c}\text { Рік } \\
\text { перекладу } \\
\text { Біблії } \\
\text { (мова) }\end{array}$ & $\begin{array}{c}\text { Рік написання } \\
\text { пасіонів }\end{array}$ & $\begin{array}{c}\text { Кількість років } \\
\text { від перекладу до } \\
\text { появи пасіонів }\end{array}$ \\
\hline \multirow{2}{*}{1} & \multirow{2}{*}{$\begin{array}{c}\text { Й. Бах } \\
\text { «Страсті...»» }\end{array}$} & \multirow{2}{*}{$\begin{array}{c}1542 \text { p. } \\
\text { (німецька) }\end{array}$} & $\begin{array}{c}1727-1729- \\
\text { перша редакція }\end{array}$ & $185 \mathrm{p.}$ \\
\hline & & & $\begin{array}{c}1736 \text { р.- друга } \\
\text { редакція }\end{array}$ & 194 p. \\
\hline 2 & $\begin{array}{c}\text { О. Козаренко } \\
« \text { Страсті...»» }\end{array}$ & $\begin{array}{c}1581 \text { p. } \\
\text { (церковно- } \\
\text { слов'янська) }\end{array}$ & $1996 \mathrm{p}$. & 415 p. \\
\hline 3 & $\begin{array}{l}\text { Митрополит } \\
\text { Іларіон } \\
\text { «Страсті...» }\end{array}$ & $\begin{array}{l}1876^{17} \\
\text { (рос. мова } \\
\text { XIX ст.) }\end{array}$ & $2006 \mathrm{p}$. & $130 \mathrm{p}$. \\
\hline
\end{tabular}

15 Роллан Р. Автобиография одной забытой знаменитости. Телеман - счастливый соперник И.С. Баха. глава из книги «Музыкальное путешествие в страну прошлого», 1919. URL: http://glierinstitute.org/ukr/study-materials/3/teleman.pdf (дата звернення: 14.07.20).

${ }_{16}$ Никифоров С.Н. Георг Филипп Телеман (1681-1767): творчество, стилистика, поэтика : дисерт. канд. искусств. Москва. 2018, C. 6. URL: http://www.mosconsv.ru/upload/images/Documents/DiserCand/ nikiforov disser.pdf. (дата звернення: 17.07.20).

$17187 \overline{6}$ - рік першого повного видання Біблії в Синодальному перекладі. 
3 даних таблиці № 1 видно, що від перекладу Свангелія до появи окремого прикладу пасіонів має пройти досить часу.

Безперечно, вивчення Біблії, як літературного джерела пасіонів, пов'язано 3 явищем хронотопу. Михайло Бахтін визначає таку категорію, як «взасмозв'язок часових $i$ просторових відносин...(y дослівному перекладi «час-простір») ${ }^{18}$. Науковець стверджує, що «y літературно-художньому хронотопі має місие злиття просторових $i$ часових прикмет в осмисленому $i$ конкретному иілому. Час тут згущується, ущільнюється, стає художньо-зримим; простір же інтенсифікується, втягується в рух часу, сюжету, історії» ${ }^{19}$. Тобто константною властивістю музично-літературного жанру страстей можна вважати прояв художньої хронотопічності. Оскільки семиденний хід подій історії (Страсний тиждень) вміщено у музичний контент довжиною приблизно від 38 хвилин (у Генріха Шютца Johannes Passion) до близько трьох годин (2 г. 46 хв.) у Йоганна Баха (Matthäus-Passion). Наявність ущільнення просторово-часових координат - наочна.

У пасіонах для розкриття головного смислу приходу Христа митцями можуть бути вибрані персонажі 3 оточення Ісуса. Серед них Євангеліст, матір Месії, Іуда, Понтій Пілат, Петро та інші. Композитор вибирає учасників подій відповідно до особистого бачення необхідності персонажа в творі. Наприклад, у страстях О. Козаренка, митрополита Іларіона, Д. Дебні присутні мати Христа, Свангеліст, Іуда. Єдиним образом твору Д. Дебні, який відрізняє вищезазначені пасіони, $є$ персонаж Вероніки. У католицькій традиції Вероніка - жінка, яка витерла своїм платком обличчя Месії під час Хресної дороги на Голгофу. С версія, що на тканині залишилося справжнє зображення особи Ісуса, яке називають платком Вероніки.

Як відомо, головною діючою особою сучасних страстей, яка залишається незмінною, $є$ Христос. У Ньому зосереджені образне призначення та знакова сутність жанру: навіть, якщо всі інші герої пасіонів розчиняться у натовпі, єдиного імені Ісуса буде досить для розкриття головної ідеї жанру пасіонів. Христос - ідеал, до якого суто теоретично хоче наблизитися кожна людина, але на практиці Iсус недосяжна модель людського абсолюту.

Чим приваблює образ Месії? Насамперед поєднанням властивостей протилежних, втаємничених. Його слова-притчі сповнені енігматичних (загадкових) висловлювань, хоча в розумінні висловів Ісуса зосереджені мудрість та спокій. Він - людина-Бог, той, хто поєднує два світи: тілесний та духовний, Він - їх центр, точка перетину.

\footnotetext{
${ }^{18}$ Бахтин М.М. Формы времени и хронотопа в романе. Очерки по исторической поэтике. С. 121. URL: https://philolog.petrsu.ru/filolog/lit/bahhron.pdf.

${ }^{19}$ Там само, стор. 122.
} 
Визначення центру духовного світу надає В. Топоров: центр «всього сакрального простору відмічається вівтарем, храмом, хрестом, світовим деревом, axis mundi (з лат. «ось світу» - прим. авт.), пупом Всесвіту, каменем, світовою горою...» ${ }^{20}$. Більшості пунктів 3 вищенаведеного відповідає Месія.

Ісус - храм, доказом тому служать слова Христа: Від Івана [2:19] «Зруйнуйте ией храм, $i$ за три дні Я поставлю його!»- говорить Він, маючи на увазі Своє тіло. Будучи прибитий до дерев'яного розп'яття, Месія на деякий час ототожнюється 3 хрестом та деревом (компонентами axis mundi), взявши на себе їх певні ознаки. Отже, Ісус знаходиться в позиції осі світу - axis mundi.

Ось світу наділено двома головними властивостями (за В. Щіпковим):

1) «забезпечення зв'язку з трансиендентним ... від світу богів - до світу людей і світу пекла;

2) забезпечення зв'язку віддалених частин світу з його центром відбувається вже в горизонтальній площчині» ${ }^{21}$.

Три властивості: Бога, людини, Того, Хто спустився в пекло, розкриваються в сутності Христа. Собою Він поєднав весь хронотоп світового безмежжя. Тривимірність часового простору (за визначенням В. Топорова), можна відобразити за допомогою вертикальної вісі часового простору: «небіжчики, душі предків, демони, злі божества, хтонічні тварини - внизу; люди, тварини - посередині; птахи, янголи, вищі божества - зверху» ${ }^{22}$. (Хоча така схема не відповідає християнській уяві про існування світу).

Злиття горизонталі буття з трансцендентною вертикаллю забезпечує саме Христос. I якщо поєднання тривимірності світу уявити важко, то як відбувається зв'язок віддалених частин світу по горизонталі з центром Ісусом - зрозуміти можливо. Уже впродовж двох тисяч років горизонтальний зв'язок стає дієвим за допомогою поширення Євангелія (словесного чи музичного).

Таким чином, однією 3 цілісних властивостей пасіонів $є$ поєднання тривимірності світу (по вертикалі) та двомірності (по горизонталі) в одному опусі. Просумувавши значення вертикального (3) та горизонтального (2) показників хронотопу, знайдемо значення «божої милості або благодаті» - число п’ять. Писання вказує на благодать як

\footnotetext{
20 Топоров В. Пространство и текст. Текст: семантика и структура. Москва : Худ. лит., 1983. C. 227-284. URL: https://inslav.ru/images/stories/pdf/1983_tekst_semantika-i-struktura.pdf (дата звернення: 17.07.20).

1 Щипков В. Роль архетипа axis mundi в современном дискурсе пространства. URL: https://cyberleninka.ru/article/n/rol-arhetipa-axis-mundi-v-sovremennom-diskurse-prostranstva/viewer (дата звернення: 17.07.20).

22 Топоров В. Пространство и текст. Текст: семантика и структура. Москва : Худ. лит., 1983. C. 227-284. https://inslav.ru/images/stories/pdf/1983_tekst_semantika-i-struktura.pdf (дата звернення: 17.07.20).
} 
характеристику Христа: 1 Кор. [16:23] «Благодать Господа намого Iсуса нехай буде з вами!». Отже, благодать є сутністю Христа, і Він Сам $\epsilon$ благодаттю для людства, центром всесвіту християн.

Феноменом жанру пасіонів $є$ злиття властивостей протилежносуперечливих, оскільки в основі жанру про страждання - радісна новина (Свангеліє). Поєднання такого плану протиставлень розкриває антиномічну якість жанру пасіонів. Так, розповіді про страждання приділяється більша частину тексту. Доведемо це емпіричним шляхом. В Свангелії від Матвія 26, 27 та 28 глави присвячені розповіді про останні дні Ісуса. Момент, коли Месія іде назустріч зраднику - Іуді вважаємо початком Христових страждань.

Від Матв.[26:46]: «Уставайте, ходім, ось наблизився Мій зрадник!». У таблиці 2 наведені дані щодо співвідношення кількості «страсних» та «радісних» віршів у Євангелії від Матвія, розпочинаючи з 26 вірша.

Таблиця 2

\begin{tabular}{|c|c|c|c|c|}
\hline $\begin{array}{c}\text { Свангеліс } \\
\text { від Матвія }\end{array}$ & $\begin{array}{c}\text { Вірші про } \\
\text { страждан- } \\
\text { ня Христа }\end{array}$ & $\begin{array}{c}\text { Кількість } \\
\text { «страсних» } \\
\text { віршів }\end{array}$ & $\begin{array}{c}\text { Вірші про } \\
\text { воскресіння } \\
\text { Христа }\end{array}$ & $\begin{array}{c}\text { Кількість } \\
\text { «радісних» } \\
\text { віршів }\end{array}$ \\
\hline 26 глава & № 46-75 & 29 & 0 & 0 \\
\hline 27 глава & № 1-66 & 66 & 0 & 0 \\
\hline 28 глава & № 1-5 & 5 & № 6-20 & 15 \\
\hline $\begin{array}{c}\text { Сумарна } \\
\text { кількість }\end{array}$ & & 100 & & 15 \\
\hline У відсотках & & $\mathbf{8 7}$ & & $\mathbf{1 3}$ \\
\hline
\end{tabular}

Після нескладних математичних підрахунків знаходимо, що розповідь про страждання Христа в трьох главах Євангелія становить близько 87 відсотків від сумарної кількості віршів «страсних» та «радісних», а розповідь про Воскресіння - всього 13 відсотків. Можна з упевненістю сказати, що приблизно така ж доля співвідношення про «страсні» та «радісні» факти присутні і в музичних пасіонах. Такий результат підтверджує парадоксальну якість пасіонів, бо згідно 3 вченням українського філософа Григорія Сковороди, видиме $\epsilon$ неважливим, а важливим $є$ невидиме. Підтвердження думки знаходимо і в Писанні: до Коринтян [4:18]: «Бо видиме дочасне, невидиме ж вічне!».

Енігматично-парадоксальною особливістю музичних Євангелій $\epsilon$ їх здатність воскресати (як Ісус), відроджуючи імена композиторів, які їх створювали. Саме євангельський жанр страстей через сто років змусив пригадати забуте ім'я Й. Баха. Як відомо, Фелікс Мендельсон доклав максимум зусиль, щоб знайдені ним бахівські партитури «Страстей за Матвієм» зазвучали, хоча й в дещо оновлено-романтичному варіанті. 426 
Іншими словами, Євангеліє допомогло всій творчості генія доби бароко відновитися із забуття. Животворча енергія євангельської музики криється в Словах Бога, які найбільш повно розтлумачує Синодальний переклад: 1 Цар. [2:30] «...Я прославлю прославляющих Меня...»²3.

Говорячи про пасіони як про п'яте Свангеліє треба назвати ще один компонент, який дає змогу жанру впродовж п'яти століть бути затребуваним. Важливою характеристикою пасіонів виступає їх музичний складник. За словами російського науковця В'ячеслава Медушевського, саме в музиці «...дивовижно виражений $<\ldots>$ закон взаємодії життєвої горизонталі і божественної вертикалі, що піднімає все земне до небес і проводить у небесне» ${ }^{24}$.

Підсумовуючи, визначимо деякі властивості жанру пасіонів як п'ятого Євангелія:

1) смність жанру (у слові «пасіони» зібрано всю програму Свангелія);

2) персоніфікованість жанру, оскільки жанр присвячено долі окремої особи;

3) прояв художньої хронотопічності (часово-просторова властивість);

4) акумулююча особливість - злиття тривимірності світу (по вертикалі) та двомірності (по горизонталі) в одному опусі;

5) антиномічна якість (в основі жанру про страждання - радісна новина);

6) енігматично-парадоксальна особливість - в здатності відроджуватися;

7) нескінченність, оскільки віддзеркалюють той час, в який пишуться.

Розуміючи нескінченність теми про життя та смерть Христа, іiі значущість для кожної віруючої людини, оцінюючи важливість історичних подій, описаних у Біблії, композитори сучасності все більше звертаються до жанру пасіонів, експериментуючи 3 ï жанровими структурами.

\section{2. Жанрові екзістенції пасіонів третього тисячоліття}

На початку третього тисячоліття композиторську увагу все більше сфокусовано на жанрах із сакральним наповненням. Жанр пасіонів, будучи структурою рухомою, нині все частіше стає основою для композиторських експериментів та пошуків. Сучасні пасіони приймають різні форми, наповнюючись ознаками часу, в якій створюються. 3 кінця XX століття 3'являються твори, в яких темі Христа відведено другорядну роль. Таким, наприклад, $є$ твір «Страсті по дівчинці із

\footnotetext{
23 Библия. Синодальний перевод. URL: https://allbible.info/bible/sinodal/1ki/1/ (дата звернення: 17.07.20)

24 Медушевський В. Евангелие как сущность божественной красоты музыки. URL: https://www.musnotes.com/v-v-medushevsky/Medushevsky3/ (дата звернення: 17.07.20).
} 
сірниками» (“The Little Match Girl Passion”, 2007) американця Девіда Ленга. В його страстях образ та життя Христа спроєктовано на історію дівчинки, яка проходить свій життєвий шлях подібно до Ісуса.

Зосередимо увагу на трьох різноспрямованих пасіонах сучасності. У фокусі дослідження знаходяться: українські «Страсті Господа Нашого Ісуса Христа» О. Козаренка (1996), твір "The Passion of the Christ Symphony" (2005) американського композитора Джона Дебні та «Страсті за Матвієм» росіянина митрополита Іларіона (2006). Сучасні митці, переосмислюючи наявний музичний матеріал композиторів попередніх епох, експериментуючи 3 жанром страстей, проявляють різне відношення до інструментальної та вокальної складових частин, з яких складаються сучасні пасіони.

Так, Джон Дебні (автор музики до фільму «Страсті Христові») в своїй симфонії-ораторії зосереджує увагу на симфонічності твору, оскільки:

- назва твору "The Passion of the Christ Symphony" вказує на першочергову вагомість оркестрової партії;

- симфонічна увертюра "Prologue. The Garden" є початком твору;

- вісім $з$ дев'яти (за винятком шостої) частин твору розпочинаються 3 оркестрового звучання.

Щодо пасіонів О. Козаренка треба відзначити, що інструментальна та вокальна складові частини в його творі використано досить збалансовано. Єдину суто оркестрову частину - "Via Doloroza" автор використовує як засіб зміни ракурсу: VII антифон, що став елементом двоплановості, розмежував собою твір навпіл. Антифон наче поєднав в одному опусі дві половини світу: до страти Христа та після. Як відомо, в Єрусалимі і нині існує вулиця Via Doloroza («Дорога скорботи»), якою йшов на страту Христос. Театральна ілюстративність музичної замальовки антифону дає змогу доволі ясно уявити шлях, яким крокував на Голгофу Месія. Такий ефект досягнуто завдяки чіткому ритму, повільному темпу, динамічному підсиленню звучності (у середині частини) та прозорому тембру звучання (на початку частини та наприкінці).

На унікальність пасіонів українського композитора вказує оригінальна основа його твору - Страсні антифони православної Служби Дванадцяти Євангелій, в яких використано прадавню Острозьку монодію. Задля написання свого твору композитор взяв десять 3 п'ятнадцяти антифонів, відібравши $з$ кожної частини лише окремі, головні тези-речення. До одноголосної Острозької мелодійної лінії ранньомодерної доби композитор додав не тільки гармонію, а й власний музичний текст.

Так, авторська музична мотив-теза $(\boldsymbol{a}-\boldsymbol{f}$-g-f) стане лейтмотивом пасіонів по-українськи та згодом перетвориться на тему Iсуса. Спираючись на чотиризвучність, така тема наче спрямована на всі кути 428 
світу, як і хрест, на якому розп'яли Христа. «У Стародавньому світі слово «хрест» часто асоиіювалося зі стратою через розп'яття... У першому столітті по Р. Х. розп'яття було найпотужнішим засобом залякування для придушення повстань $і$ політичних чвар у римських провіниіях. Розп'яттю передувало бичування» ${ }^{25}$.

Фокусуючи увагу на творі митрополита Іларіона, треба відзначити, що в пасіонах більш вагомою $є$ роль Свангеліста та хору, на противагу значущості оркестру. Доказом тому слугує факт, що «Страсті за Матвієм» розпочинаються 3 проповіді. Щодо визначення особливостей своїх страстей сам композитор-єпископ відзначає, що його твір «..відповідае формату Баха, окрім того, що він наповнений православним змістом...» ${ }^{26}$. Розкриваючи задум про написання свого твору, композитор-священник зазначає, що «на відміну від пасіонів Баха, тут немає лібрето, тільки євангельське оповідання, яке розповідає протодиякон російською мовою $i$ знайомим у православній иеркві чином» ${ }^{27}$. Сам автор музики вже на початку твору бере на себе функцію проповідника, впродовж твору стане наратором Євангелія. Появу композитора-євангеліста на сцені в одежі священника можна трактувати як прояв двоплановості, який, з одного боку, є оригінальною знахідкою, а з іншого боку, стає елементом театральності.

Стираючи межу між церквою та концертною залою, композитор підкреслює першочергову значимість Слова. Так, вступна промовапроповідь митрополита Іларіона передує оркестровому вступу. Надалі під час прочитання Євангельського тексту музичний складник стає супроводом, виконуючи другорядну роль.

Продовжуючи композиторські пошуки у форматі пасіонів, сучасні композитори розуміють, що безліч напрямів для нового прочитання творів надає мова. Щонайменше, страсті можуть бути написані:

- прадавньою мовою Біблії;

- у сучасному форматі прадавньої мови;

- будь-якою мовою світу;

- у творі можуть бути використано мікст мов та діалектів.

Так, унікальною знахідкою для пасіонів О. Козаренка стала прадавня монодія, яку викладено церковнослов'янською. В основі українських страстей - одноголосний Острозький наспів (варіант Київського як частки знаменного розспіву) - один 3 найдавніших слов'янських піснеспівів ранньомодерної доби.

\footnotetext{
${ }^{25}$ Райкен Л., Уилхойт Д., Лонгман Т. Словарь библейских образов. URL: https://azbyka.ru/otechnik/ Spravochniki/slovar-biblejskih-obrazov (дата звернення: 17.07.20).

26 Там само.

27 Митрополит Иларион. Russian Orthodox Metropolitan Hilarion Alfeyev on Music and Faith. URL: https://president.catholic.edu/archive/inauguration/hilarion-alfeyev.html\#Full_text (дата звернення: 17.07.20).
} 
Використовуючи в пасіонах часовий синтез мов, композитори досягають ефекту сумарного накопичення, пролонгованості життя пасіонів. Останні, таким чином, вбирають у себе найкращі ознаки попередніх часів, оскільки музичний матеріал, що зберігся до сьогодення (як, наприклад, Острозький наспів), проходить ретельну перевірку часом.

Звертаючись до мовного чинника пасіонів, митрополит Іларіон у своєму творі зібрав різні види однієї мови. Композитор поєднав: церковнослов'янські тексти (частини «Тече глаголя Іуда»; «Един от вас предаст Мя»); російську мову ХІХ ст. (Синодальний переклад, звернення Свангеліста) та розмовну російську мову XXI століття. У симфонії-ораторії Джона Дебні задіяні: арамейська (як одна 3 розмовних мов Палестини за часи життя Ісуса), латинь та італійська.

Цілком органічно, що оновлення пасіонів сучасності відбувається також і за рахунок нових тембральних знахідок. Наприклад, Д. Дебні, щоб передати більш реальну атмосферу Близького Сходу за часів Христа, насичує об'єм звучності класичних голосів етнічним звучанням тембру мецо-сопрано (в другій, четвертій, сьомій частинах, в епілозі). Нестандартним у пасіонах Д. Дебні є і склад оркестру, до якого додано голоси органу, арфи, дуету національних дерев'яних духових інструментів - дудуків (у складі провідного та дам-дудука). Останні духові інструменти визнані шедевром Всесвітньої нематеріальної культурної спадщини ЮНЕСКО та $є$ доволі поширеними в країнах Близького Сходу. До особливих характеристик звучання дудуків слід віднести їх насичений оксамитовий тембр та теплу обертоновість звучності, які роблять окремі частини твору більш ліричними та виразними. Задля підкреслення внутрішнього стану Бога-Сина в момент останнього земного спілкування з Богом-Батьком композитор у шостій частині вводить м'яко-ліричне звучання пари дудуків (VI ч. названо "Nailed To The Cross. Jesus Dies On The Cross" або «Прибито до хреста. Ісус помирає на хресті»). Тембральну особливість звучання дудука представлено композитором також у першій, третій, четвертій частинах твору.

Експериментуючи з інструментальним складом оркестру, український композитор О. Козаренко вплітає в музичну тканину своїх пасіонів звучання барочного інструменту - органу. Етнічною знахідкою для пасіонів стане також застосування звукозображальних можливостей фрусти. Останній - дерев'яний музичний інструмент, що впродовж століть використовують різні народи світу.

Що стосується пасіонів митрополита Іларіона, то треба відзначити відсутність у його творі тембральної окраски інструментів духової та 
ударної груп. Присутність у оркестрі однієї лише струнної групи робить його страсті доволі прозорими та легкими.

Як відомо, структурними вокальними елементами пасіонів $є$ арії, речитативи, хорали та хори. Проаналізувавши їх використання у вищезазначених творах, зробимо деякі локальні висновки. Сучасні автори комбінують співвідношення структурних одиниць пасіонів залежно від особистого бачення. Наприклад, митрополит Іларіон виводить на перший план значимість у творі Слова, ставлячи речитатив на перше місце (твір розпочинається 3 проповіді, надалі слова Євангеліста звучать на тлі оркестру). Д. Дебні у своїх пасіонах зовсім відмовляється від речитативу. У пасіонах О. Козаренко і слово, і музика, і речитативи, і сольні номери використано доволі збалансовано.

Свої особливо-суб'єктивні погляди викладання музичного матеріалу має застосувати кожний композитор як у разі використання структурних одиниць пасіонів, так і у разі розкриття їх головного персонажу. Наприклад, митрополит Іларіон, як і Й. Бах, не персоніфікує Христа: у цих пасіонах Мессія не має жодного номера. У Д. Дебні голос Ісуса (тенор) звучить вже в першій частині твору в соло - епізоді "Prologue. The Garden". Музичною промовою Христа наповнені III, VI, частини, епілог. В пасіонах О. Козаренка голос Ісуса звучить у II антифоні. В п'ятій частині розміщено арію Христа (соло тенора). Такий антифон єдина частина, в якій автор залишає недоторканим аутентичний запис нотного тексту. Без тактового дроблення музична мова п'ятої частини символізує собою чистоту та святість, якими був наділений сам Ісус.

У сучасних пасіонах використання хорала $є$ не таким важливим, як це було в барокову добі. Цей факт пояснюється втратою найважливішої функції такої структурної одиниці страстей, що раніше полягала в сумісному співі 3 парафіянами. Застосування хоралів до сучасних пасіонів допомагає композиторам підкреслити масштабність подій. У Джона Дебні в формі хоралу викладено останню частину "Epiloge...". Маючи в своїй основі грандіозне, життєстверджуюче, мажорно-піднесене звучання 3 опорою на фігуру типу anabasis, в останній частині страстей на весь світ звучить піднесене “Alleluia!”.

Незмінним учасником більшості сучасних пасіонів, як і в попередні епохи, залишається хор, що і тепер є головним жанровим структурним елементом страстей. Хоровий спів доволі часто несе на собі головне сенсове навантаження пасіонів. Як доказ тому хорова арка з початкового та заключного хорів у пасіонах Баха, митрополита Іларіона.

Впродовж багатьох років композитори не перестають спиратися на вершинні пасіони геніального композитора епохи бароко. Так, російський композитор митрополит Іларіон упродовж всього твору неодноразово використовує барочні фігури (anabasis, catabasis, circulatio 
та ін.). У його страстях наявні алюзії на звучання з Бахівських страстей: інтонації 3 соло альта нагадують відомий номер пасіонів Баха. Спираючись у своєму творі на пасіони Баха, композитор підкреслює: «Бах - ие колос; його музика містить універсальний елемент, який $\epsilon$ всеосяжсним» ${ }^{28}$. Використовуючи в окремих частинах пасіонів поліфонічну техніку письма (№ 8 та № $27 є$ оркестровими фугами), митрополит Іларіон намагається «втілити мрію великого російського композитора Михайла Глінки в реальність, а саме «одружити» західну фугу з російським иеерковним співом» ${ }^{29}$.

Простота музичних інтонацій у «Страстях...» композиторасвященника, демократичність мелодійного висловлювання підкреслюють зрозумілі, суворі форми його страстей (так, дві частини складаються 3 48 номерів, серед яких дві фуги); класичні гармонії (з опорою на головну тональність - c-moll). Розвиток музичних тем твору відбувається за рахунок повторності, варіантності, за допомогою використання «золотих» секвенцій. Дублювання, імітації застосовуються композитором як у оркестрі, так і у хорі. Завдяки вищенаведеним засобам твір здається доволі знайомим. Останній хоровий «Смерть Твою, Господи, возвещаем» звучить хоча й трагічно, але піднесено.

Підсумовуючи, відзначимо, що сучасні композитори продовжують творчі експерименти з пасіонами, роблячи їх жанрову форму рухомою, здатною приймати різні форми.

\section{ВИСНОВКИ}

Недостатня вивченість жанру пасіонів у площині українського музикознавства робить тему актуальною для науковців. Сучасні страсті, що продовжують з'являтися, потребують належного аналізу, порівняння задля визначення напрямів спрямованості композиторської думки третього тисячоліття. Нові страсні жанрові структури мають бути проаналізовані задля висвітлення основних тенденцій розвитку українських страстей у контексті пасіонів світового культурного простору.

Історія життя, страти та воскресіння Христа - основа музичних страстей. Свангельський наратив, переломлений крізь музичну призму, вже більше п'ятисот віків приваблює увагу слухачів. Композитори, створюючи музику до пасіонів, заздалегідь мають справу $з$ досконалим текстом, викладеним у Біблії. Унікальність літературної основи страстей - одна $з$ причин актуальності жанру. В роботі виявлені ознаки феноменальності жанру пасіонів: їх смність, персоніфікованість,

\footnotetext{
${ }^{28}$ Митрополит Иларион. Russian Orthodox Metropolitan Hilarion Alfeyev on Music and Faith. URL: https://president.catholic.edu/archive/inauguration/hilarion-alfeyev.html\#Full_text. (дата звернення: 17.07.20).

${ }_{29}^{29}$ Там само. 
прояви художньої хронотопічності, акумулююча особливість, антиномічна та енігматично-парадоксальна якості, а також прояв Свангельської нескінченності.

У XX-XXI ст. 3'являються страсні композиції, що містять у собі жанрові ознаки синтезу, поліморфності, як і багато жанрових структур сучасності. Мистецькі пошуки, розпочаті Романтичною добою, дали змогу всім жанровим канонам звільнитися від строгих шаблонів та правил епохи класицизму, що триває і нині.

У роботі виявлені важливі аспекти сучасних пасіонів: органічне поєднання, злиття, синтез їх різних складників. Так, сучасна модель жанру може мати міжконфесійне прочитання (Острозькі наспіви у творі О. Козаренка та православні тексти у страстях митрополита Іларіона). Сучасні композитори оригінально наповнюють страсті обов'язковими структурними одиницями (аріями, хоралами, хорами, речитативами), варіативно ставлячись до їх використання. Д. Дебні взагалі відмовляється від речитативу. Для виконання творів композитори-сучасники застосовують як традиційний інструментарій, так i маловживаний. Переосмислюються і тембрально-вокальні засоби музичної виразності. У одному творі можуть поєднуватися різні мови та ії діалекти.

Багато питань стосовно давнього жанру потребують подальших досліджень. Композитори мають різні поштовхи до написання композицій, у кожної з яких є своя історія виникнення і особиста довжина життя, що іноді переживає цілі епохи, як безсмертні пасіони Баха.

\section{АНОТАЦІЯ}

На зламі останніх століть композитори все більше уваги приділяють творам 3 духовним змістом. 3'являється музичний пласт творів, який потребує всебічного дослідження. Смний, масштабний жанр пасіонів має бути вивчено задля визначення новітніх напрямів діяльності українських композиторів у контексті світового мистецтва. Зразками досліджуваних пасіонів стали три різновекторні пасіони О. Козаренка, Д. Дебні та митрополита Іларіона. У роботі емпіричним шляхом доведені характерні властивості феномена жанру пасіонів, які дають змогу говорити про його універсальність та позачасову сутність. Вперше проведено паралель між філософською категорією axis mundi та страстями, а також виявлено антиномічну якість пасіонів, оскільки жанр про страждання базується на «радісній звістці».

\section{ЛІТЕРАТУРА}

1. Бахтін М.М. Формы времени и хронотопа в романе. Очерки по исторической поэтике. С. 121-290. URL: https://philolog.petrsu.ru/filolog/ lit/bahhron.pdf (дата звернення: 14.07.20). 
2. Біблія / в перекл. Огієнка I. URL: https://bibleonline.ru/bible/ubio/jhn-3/ (дата звернення: 17.07.2020).

3. Библия / Синодальный перев. URL: https:/allbible.info/ (дата звернення: 17.07.20).

4. Коменда О. Жанрово-інтонаційні джерела тематизму Олександра Козаренка: інтонаційні відкриття композитора. С. 141-157. URL: https://core.ac.uk/download/pdf/153584885.pdf. (дата звернення: 17.07.2020).

5. Коменда О. Універсальна творча особистість в українській музичній культурі : дис. ... докт. мист. : 17.00.03. Нац. муз. акад. Укр. ім. Чайк. Київ. 2020. 519 c. URL: http://knmau.com.ua/wp-content/uploads/ komenda-dysertatsiya.pdf. (дата звернення: 17.07.2020).

6. Медушевський В. Евангелие как сущность божественной красоты музыки. URL: https://www.musnotes.com/v-v-medushevsky/Medushevsky3/ (дата звернення: 17.07.20).

7. Никифоров С.Н. Георг Филипп Телеман (1681-1767): творчество, стилистика, поэтика : дис.... канд. искусств. : 17.00.02. Моск. гос. конс. им. Чайк. Москва. 2018. 324 c. URL: http://www.mosconsv.ru/upload/ images/Documents/DiserCand/nikiforov_disser.pdf. (дата звернення: 17.07.2020).

8. Рау Є. Жанр пассиона в музыкальном искусстве: общий исторический путь и судьба в XX-XXI вв. : дис. ... канд. искусств. : 17.00.02. Рос. гос. пед. ун. им. Герц. Санкт-Петербург. 2018. 329 с. URL: https://www.conservatory.ru/sites/default/files/uploads/science/.pdf. (дата звернення: 17.07.2020).

9. Райкер Л., Уилхойт Д., Лонгман Т. Словарь библейских образов / перевод Скороходова Б.А., Рыбакова O.A. URL: https://azbyka.ru/ otechnik/Spravochniki/slovar-biblejskih-obrazov/723. (дата звернення: 17.07.2020).

10. Роллан Р. Музыкальное путешествие в страну прошлого. 1939. URL: http://glierinstitute.org/ukr/study-materials/3/teleman.pdf (дата звернення: 14.07.2020).

11. Ткаченко А. Українська сакральна монодія в сучасній композиторській творчості : дис. ... канд. мист. Львів. нац. муз. акад. ім. М. В. Лисенка. 2016. Львів. 183 с. URL: http://conservatory.lviv.ua/wpcontent/uploads/2016/09/diss-tkachenko.pdf (дата звернення: 17.07.2020).

12. Топоров В. Текст: семантика и структура. Москва. 1983. C. 227-284. URL: https://inslav.ru/images/stories/pdf/1983_tekst_semantikai-struktura.pdf. (дата звернення: 17.07.20).

13. Щіпков В. Роль архетипа axis mundi в современном дискурсе пространства. URL: https://cyberleninka.ru/article/n/rol-arhetipa-axismundi-v-sovremennom-diskurse-prostranstva/viewer (дата звернення: 17.07.20). 
14. Юнак Д. О. «Миф или действительность». URL: http:// www.nauka.bible.com.ua/mif/index.htm (дата звернення: 17.07.20).

15. Contemporary Music and Spirituality / Robert Sholl, Sander Van Maas edition. 2016. URL: https://www.routledge.com/Contemporary-Music-andSpirituality-1st-Edition/Sholl-Van-Maas/p/book (дата звернення: 17.07.2020).

16. Yarbrough O.L. Engaging the Passion: Perspectives on the Death of Jesus. 2015. https://www.jstor.org/stable/j.ctt13wwwjn. (дата звернення: 17.07.2020).

\section{Information about author:} Savoniuk H. O.,

Applicant at the Department of Music History and Musical Ethnography Odessa National A. V. Nezhdanova Academy of Music 63, Novoselsky str., Odessa, 65023, Ukraine Teacher

"Naukova Zmina" Lyceum 21V, Petro Hryhorenko Avenue, Kyiv, 02000, Ukraine 